\begin{tabular}{|c|c|} 
Available online at: http://ejournal-balitbang.kkp.go.id/index.php/ifrj \\
e-mail:ifrj.puslitbangkan@ gmail.com \\
INDONESIANFISHERIESRESEARCHJOURNAL \\
Volume 27 Nomor 2 December 2021 \\
p-ISSN: 0853-8980 \\
e-ISSN: 2502-6569
\end{tabular}

\title{
GENETIC CHARACTERIZATION OF DWARF SNAKEHEAD, Channa gachua (Hamilton, 1822), FROM TWO POPULATIONS BASED ON 16S rRNA GENE
}

\author{
Ragil Pinasti ${ }^{\star 1}$, Warisatul IImi and Tuty Arisuryanti ${ }^{1}$ \\ ${ }^{1}$ Laboratory of Genetics and Breeding Faculty of Biology, Gadjah Mada University, Jl. Teknika Selatan, Senolowo, Sleman, \\ Yogyakarta 55281, Indonesia \\ Received; June13-2019 Received in revised from August 12-2021; Accepted August 20-2021
}

\begin{abstract}
Indonesia is one of the countries with high biodiversity of freshwater fishes. One of the freshwater fish that has widely distribution in Asia with high economic potency for ornamental fish is dwarf snakehead. However, research on genetic characterization of dwarf snakehead from Indonesia is very limited. Therefore, this research aimed to compare genetic characterization of the dwarf snakehead from rice field irrigation at Donomulyo Village (Malang, East Java) and from Keji River (Magelang, Central Java). This study used a PCR method with universal primers: 16Sar and 16Sbr. The data obtained in this study were then analyzed using DNASTAR, BLAST, Mesquite, MEGA, DnaSP, and NETWORK. The results revealed the genetic distance between dwarf snakehead from rice field irrigation at Donomulyo Village and from Keji River was 1.36\%. The divergence of GC content, haplotype number, variables sites, haplotype diversity, and nucleotide diversity in both populations exist. The results of this study are expected to arrange 16S mitochondrial DNA Library of dwarf snakehead from Indonesia which is useful for a reference in the conservation and utilization and management of dwarf snakehead in their habitat.
\end{abstract}

Keyword: Dwarf snakehead; genetic characterization; 16S rRNA gene

\section{INTRODUCTION}

Dwarf snakehead, Channa gachua (Hamilton, 1822), is a native fish from Asia and widely distributed from West Afghanistan to Indonesia through South and Central Asia (Kottelat, 2013). The fish is usually found in shallow waters, rivers, reservoirs, swamps, rice fields and irrigation at $\mathrm{pH}$ 6-7 and temperatures 10-28! (Ilmi \& Arisuryanti, 2018). The fish has an elongated body reaching a size of $18-36 \mathrm{~cm}$ accompanied by an elongated dorsal fin, the mouth filled with teeth and has the superior type of mouth, and around caudal type of tail. The fish size from genus Channa is generally small, but $C$. gachua is the smallest. In addition, the fish has many color variations on their bodies, so they are suitable for use as ornamental fish (Gustiano et al., 2021). Furthermore, the albumin content in the fish can be used for therapy to healing wounds and reducing post-surgery pain (Ab Wahab et al., 2015; Hariati et al., 2019)

In order to increase the production of the fish in Indonesia through a breeding program, genetic characterization of the fish species has to be done using molecular approaches. The mitochondrial genome has been used as an effective tool for phylogenetic and population genetic analyses in vertebrates. One of the mitochondrial genes that is commonly used to explore the phylogenetic relationships of fishes at various taxonomic levels is $16 S$ rRNA. The 16S rRNA gene is one of the genetic markers for investigating animal genetic variety and phylogeny. This is due to the $16 \mathrm{~S}$ mitochondrial gene is conserved, and a change of a few nucleotides within or between populations could indicate a significant degree of variation (Cawthorn et al., 2012; Yang et al., 2014). The majority of $16 S$ rRNA studies were conducted on aquatic organisms, such as red sea parrotfish (Saad et al., 2019) and striped snakehead (Arisuryanti et al., 2020). This is due to the gene being considered as maternal inheritance, lack of introns, presence of single-copy orthologous genes, lack of recombination events, and high mutation rate. Mitochondrial $16 \mathrm{~S}$ rRNA gene also contains sufficient polymorphisms to unambiguously discriminate most species due to a high number of insertions and deletions in non-peptide coding DNA. In addition, the 16S rRNA gene is ubiquitous (Faddagh et al., 2012; Srinivasan et al., 2015; Satoh et al., 2016; Hossain et al., 2019). 
Research on the genetic diversity of $C$. gachua has been carried out in several countries, including China (Zhou et al., 2019; He et al., 2019), Thailand (Tanomtong et al., 2013), Bangladesh (Ahmed et al., 2018), Malaysia, Borneo, Myanmar, Vietnam (ConteGrand et al., 2017). In Indonesia, research on the genetic characterization of $C$. gachua is very limited. The previous study carried out by IImi and Arisuryanti
(2018) revealed the nucleotide composition of the $16 S$ mitochondrial DNA Channa gachua from Keji River, Magelang, Central Java. Therefore, this study aimed to compare the genetic character of $C$. gachua from Keji River, Magelang, Central Java and $C$. gachua from rice field irrigation at Donomulyo Village, Malang, East Java.

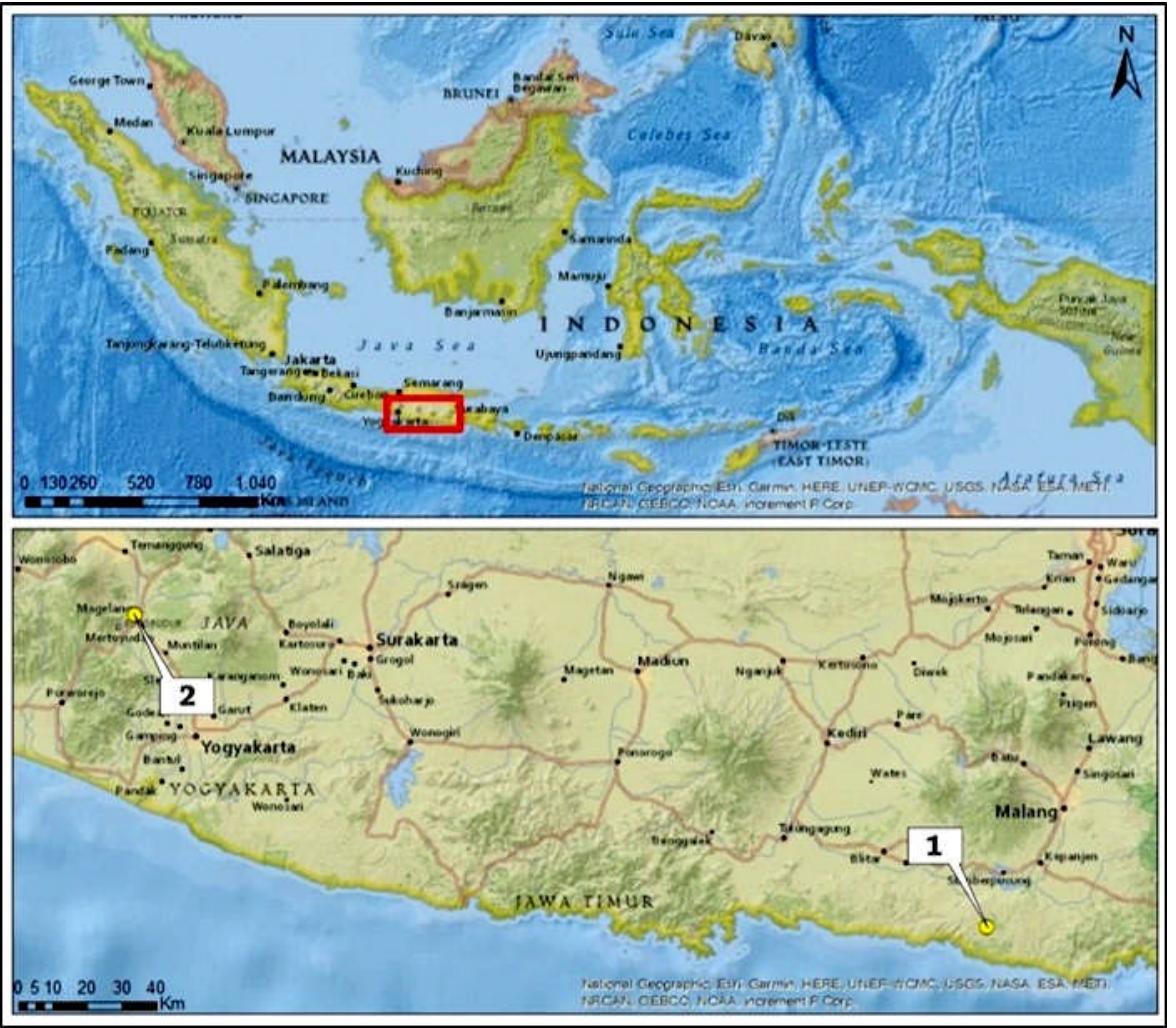

Figure 1. Map sampling collection of dwarf snakehead. (1) rice field irrigation at Donomulyo Village and (2) Keji River.

\section{MATERIALS AND METHODS \\ Sampling for Collection for 165 Mitochondrial Sequencing}

Four samples of dwarf snakehead (sample code: KTM-01, KTM-02, KTM-03, dan KTM-04) were collected from rice field irrigation at Donomulyo Village, Malang, East Java (8॰17'0"S $\left.112^{\circ} 26^{\prime} 0 " E\right)$ and two samples (sample code: KTS-01 and KTS-02) obtained from Keji River, Magelang, Central Java (7'35’34.85"S $\left.110^{\circ} 16^{\prime} 19.48 " \mathrm{E}\right)$ (Figure 1). The 50-100 mg muscle tissue of each sample was dissected with sterilized scissors and put into a $1.5 \mathrm{ml}$ sterile tube containing $99 \%$ ethanol. The muscle tissue samples were then transported to the Laboratory of Genetics and Breeding, Faculty of Biology, Gadjah Mada University (Yogyakarta, Indonesia) and stored in $-20^{\circ} \mathrm{C}$ until further investigation.

\section{DNA Extraction, Amplification, and Sequencing of $16 S$ Mitochondrial Gene: Procedure and Analysis}

Total genomic DNA was extracted using Qiagen DNEasy Blood and Tissue Kit (Qiagen, Valencia, CA, USA) following the manufacturer's protocols. The 165 mitochondrial gene from the six dwarf snakehead samples was amplified using MyTaq HS Red Mix PCR Kit for the polymerase chain reaction (PCR), and the primers used in this study was 16Sar (5'-CGCCTGTTTATCAAAAACAT-3') and 16Sbr (5'CCGGTCTGAACTCAGATCACGT-3') (Palumbi, 1996). The PCR reaction mixture for each sample consisted of $12.5 \mu \mathrm{l} \mathrm{PCR} \mathrm{mix;} 0.6 \mathrm{iM}$ primer forward; $0.6 \mu \mathrm{M}$ primer reverse; $1 \mathrm{mM} \mathrm{MgCl}$; $5.5 \mu \mathrm{lddH} 2 \mathrm{O}$; and $3 \mu \mathrm{l}$ DNA samples of the fish. The total volume of each PCR reaction was $25 \mu \mathrm{L}$, then amplified under the 
thermal conditions following Arisuryanti et al. (2020). All of the PCR products were visualized using electrophoresis on a $1 \%$ agarose gel buffered with Tris-Acetate-EDTA (TAE), stained with FloroSafe (1st Base) nucleic acid stain, and visualized under UV light. All of the samples were then sent to First Base Services (Malaysia) through P.T. Genetics Science (Jakarta) for DNA purification and sequencing. The PCR products were sequenced bi-directionally by using both primers (16Sar and 16Sbr) and the Big Dye Terminator Ver. 3.1. sequencing kit (Applied Biosystems). The sequencing reactions were loaded into ABI 3730xl Genetic Analyzer (Applied Biosystems).

Chromatograms of the dwarf snakeheads investigated in this study were checked and assembled using SeqMan and edited manually using EditSeq Pro Program Lasergene DNASTAR software package. The sequence of each sample was verified using the BLAST program of NCBI. Multiple sequence alignments were done with Opal in MESQUITE v.3.61 (Maddison \& Maddison, 2019) and ClustalW in MEGAX (Kumar et al., 2018). The genetic distance of the samples was analyzed using the MEGAX program with the Kimura 2 parameter model. The phylogeny relationship was reconstructed using the Neighbor-Joining (NJ) method in the MEGAX program using the Kimura 2 parameter model and 1,000 bootstraps. Genetic diversity indices such as the GC content, number of haplotypes, polymorphic sites, haplotype diversity and nucleotide diversity were analyzed using DnaSP v6.12.01 (Rozas et al., 2017). A haplotype network was analyzed using NETWORK 10.2.0.0 program with the Median Joining method (https://www.fluxus-engineering.com). Five dwarf snakeheads (Channa gachua) recorded at GenBank (accession number: KU986900, MH699846, KU238074, NC036948, MF924390) were used for comparison purposes. In addition, two species $C$. striata (KU986899) and C. punctata (EU342183) were used as outgroups.

\section{RESULTS AND DISCUSSION Results}

All of the dwarf snakehead samples from rice field irrigation at Donomulyo Village (sample code: KTM01, KTM-02, KTM-03 and KTM-04) and from Keji River (sample code: KTS-01 and KTS-02) were successfully amplified and resulted $539 \mathrm{bp}$ in fragment length (Figure 2). The nucleotide BLAST analysis from NCBI (https://blast.ncbi.nlm.nih.gov) revealed that all of the dwarf snakehead samples examined in this study have 99\% similarity with Channa gachua with accession number KU986900 recorded at GenBank. All of the $C$. gachua samples from rice field irrigation at Donomulyo Village and Keji River has been registered at GenBank

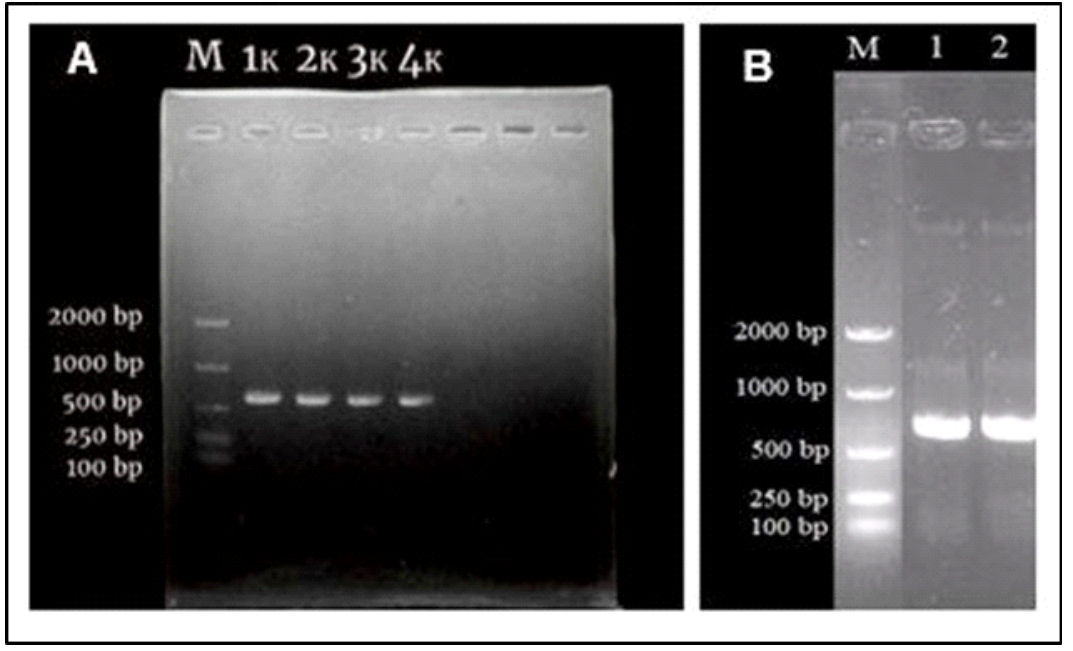

Figure 2. PCR amplification of the dwarf snakehead specimens from Rice Field Irrigation at Donomulyo Village, Malang, East Java (A) and from Keji River, Magelang, Central Java (B) using 16Sar and $16 \mathrm{Sbr}$ primers and were separated by electrophoresis in $1 \%$ gel electrophoresis $(\mathrm{M}=$ size marker 2000 bp, 1K=KTM-01, 2K=KTM-02, 3K=KTM-03, 4K=KTM-04, 1=KTS-01, 2=KTS-02).

with accession number MZ781215- MZ781220.

Based on the 539 bp fragment length, the estimate of genetic variation of $C$. gachua from rice field irrigation at Donomulyo Village and Keji River can be seen in Table 1. The result exhibited the GC content of $C$. gachua from Keji River was slightly higher than that of $C$ gachua from rice field irrigation at Donomulyo Village. The difference of GC content of $16 S$ mitochondrial gene between C. gachua from rice field irrigation at Donomulyo Village and $C$. 
Table 1. Estimates of genetic variation of $C$. gachua from two populations based on 165 mitochondrial gene. KTM is sample code of $C$. gachua from rice field irrigation at Donomulyo Village and KTS is sample code of $C$. gachua from Keji River

\begin{tabular}{lcccccc}
\hline $\begin{array}{l}\text { Sample } \\
\text { code }\end{array}$ & $\begin{array}{c}\text { GC } \\
\text { content }\end{array}$ & $\begin{array}{c}\text { Haplotype } \\
\text { number }\end{array}$ & $\begin{array}{c}\text { Variable } \\
\text { sites }\end{array}$ & $\begin{array}{c}\text { Parsimony } \\
\text { informative } \\
\text { sites }\end{array}$ & $\begin{array}{c}\text { Haplotype } \\
\text { diversity }\end{array}$ & Nucleotide diversity \\
\hline KTM & $46.71 \%$ & 2 & 1 & 0 & $0,500 \pm 0,265$ & $0,00083 \pm 0,00091$ \\
KTS & $47.9 \%$ & 2 & 5 & 0 & $1,00 \pm 0.250$ & $0.00873 \pm 0.0000190$ \\
\hline
\end{tabular}

gachua from Keji River was 1.19\%.

In addition, the results revealed that the number of variable sites, haplotype diversity and nucleotide diversity of $16 S$ mitochondrial sequences of $C$. gachua from Keji River was higher than that of $C$. gachua from rice field irrigation at Donomulyo Village. Both populations have similar haplotype numbers but different variable sites and no parsimony-informative site. In addition, there were 9 transitions on their pattern of nucleotide substitution (Table 2). If the $16 S$ sequences of both populations were analyzed together with C. gachua from GenBank database, 7 haplotypes with 22 variable sites and 16 parsimonyinformative were detected (Table 2 and 3 ). Haplotype diversity and nucleotide diversity was $0.909 \pm 0.066$ and $0.01376 \pm 0.00184$, respectively. The 165 sequence data also exhibited the variable sites contained 17 transitions, 3 transversions, and 2

Table 2. Summary of nucleotide variations in the partial $16 S$ mitochondrial gene of $C$. gachua. Only variable sites are shown. Dots indicate identity with the $C$. gachua sequence taken from GenBank with accession number KU986900 as a reference. Number above corresponds to the nucleotide base pair position.

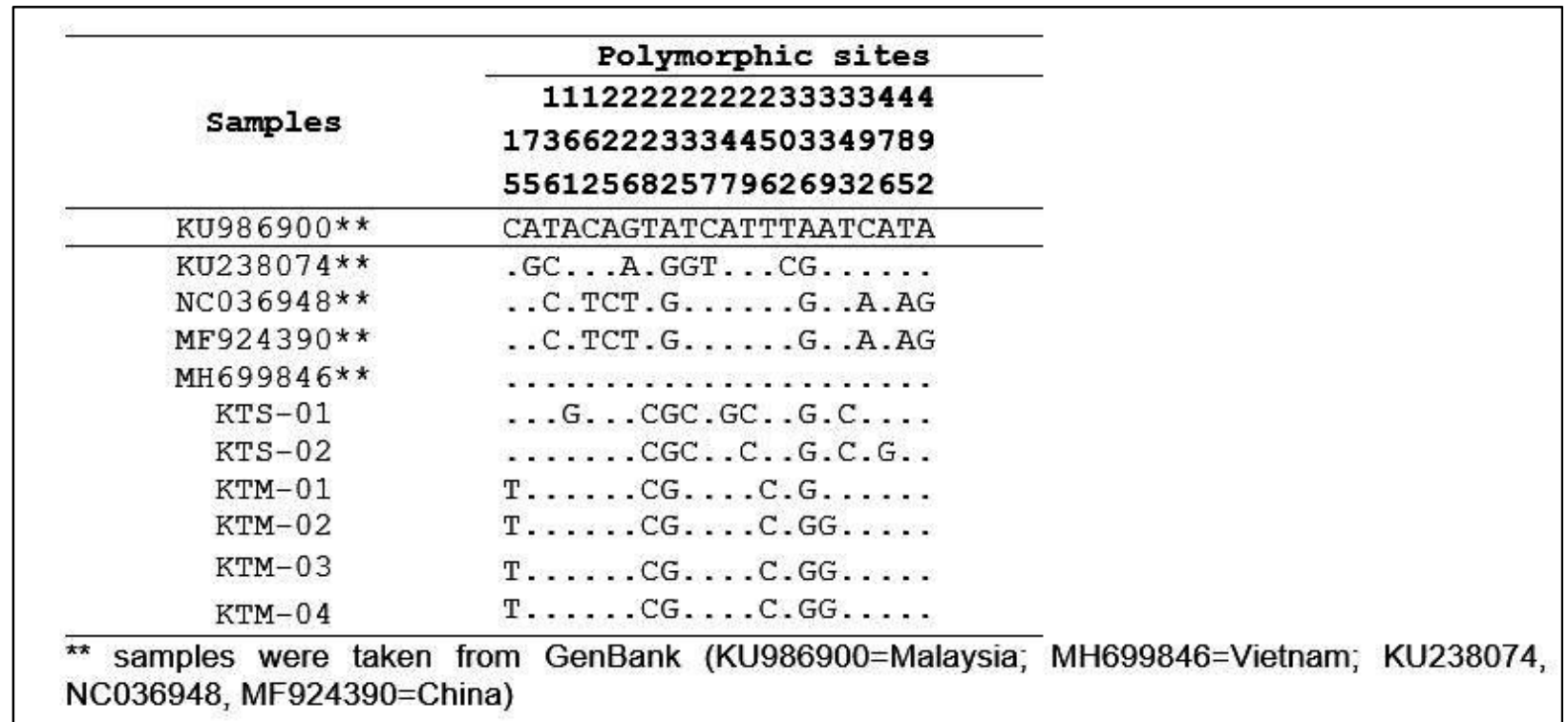

Table 3. Haplotype data of $C$. gachua from rice field irrigation at Donomulyo Village and from GenBank database based on $16 S$ mitochondrial gene.

\begin{tabular}{cccc}
\hline Haplotype & Sample & Accession Number & Location \\
\hline Hap_1 & 2 & KU986900 & Malaysia \\
Hap_2 & 1 & MH699846 & Chietnam \\
Hap_3 & 2 & NC036944 & China \\
Hap_4 & 1 & MF924390 & China \\
Hap_5 & 1 & KTS-01 & Keji River, Magelang, Indonesia \\
Hap_6 & 1 & KTS-02 & Keji River, Magelang, Indonesia \\
Rice field irrigation at Donomulyo & village, Malang, Indonesia \\
Hap_7 & 3 & KTM-01 & Rice field irrigation at Donomulyo \\
& & KTM-02 & KTM-03 \\
KTM-04 & & village, Malang, Indonesia \\
\hline
\end{tabular}


multiple substitutions.

The haplotype networking among the $C$. gachua from rice field irrigation at Donomulyo Village (East Java, Indonesia), C. gachua from Keji River (Central Java, Indonesia), and C. gachua from other countries can be seen in Figure 3. One and another haplotype was separated with 5-22 mutation points. The C. gachua from rice field irrigation at Donomulyo village and C. gachua from Keji River was separated with 9 mutation points, whereas $C$. gachua from rice field irrigation at Donomulyo village and $C$. gachua from Malaysia and Vietnam was separated only with 6 mutation point. This indicates the $C$. gachua from the three populations were genetically close compared with $C$. gachua from Keji River. Either $C$. gachua samples from rice field irrigation at Donomulyo Village or C. gachua from Keji River formed into two different haplotypes in the same haplogroup. This finding can be used as a molecular

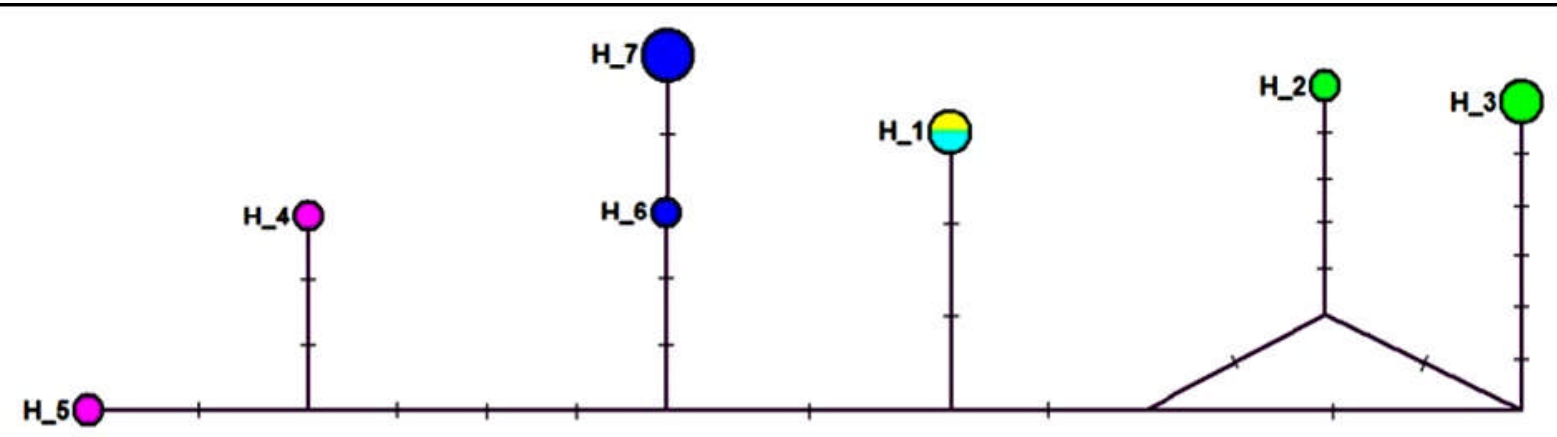

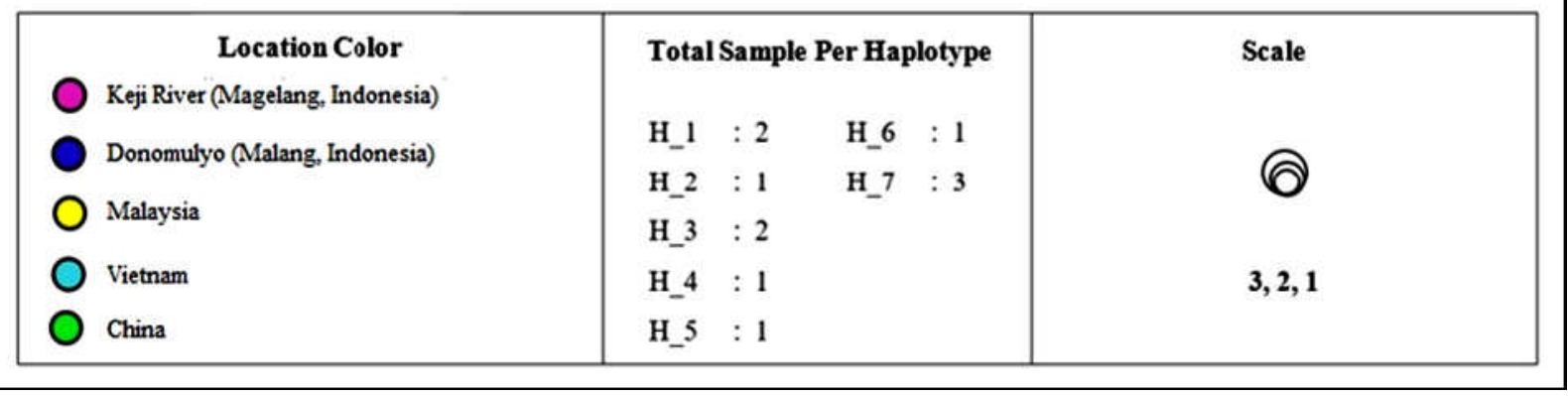

Figure 3. Construction of Haplotype Networking from $539 \mathrm{bp}$ of $16 S$ sequence data.

marker for both populations.

The genetic distance between $C$. gachua from rice field irrigation at Donomulyo village and $C$. gachua from Keji River was $1.36 \%$, whereas the genetic distance between $C$. gachua from rice field irrigation at Donomulyo village and $C$. gachua from other countries was range $1.08-2.02 \%$ (Table 4 ). The genetic distance between $C$. gachua from rice field irrigation at Donomulyo Village and $C$. gachua from Malaysia, Vietnam, and China was
$1.08 \%, 1.08 \%$, and $1.96 \%$ respectively. The genetic distance between $C$. gachua samples from rice field irrigation at Donomulyo village, Malang and $C$. gachua from Keji River, Magelang was higher than $C$. gachua from Malaysia and Vietnam. The same value of genetic distance between C. gachua samples from rice field irrigation at Donomulyo village (Malang, Indonesia) and C. gachua from Malaysia and Vietnam which was $1.08 \%$ revealed that the $C$. gachua from the three populations were close genetically compared

Table 4. Percentage of genetic distance between $C$. gachua from rice field irrigation at Donomulyo Village (KTM) and Keji River (KTS), and GenBank database

\begin{tabular}{|c|c|c|c|c|c|c|c|}
\hline & 1 & 2 & 3 & 4 & 5 & 6 & 7 \\
\hline 1.KU238074** & - & & & & & & \\
\hline 2.NC036948** & 1.88 & - & & & & & \\
\hline 3.MF924390** & 1.88 & 0.00 & - & & & & \\
\hline 4.KU986900** & 1.50 & 1.69 & 1.69 & - & & & \\
\hline 5.MH699846** & 1.50 & 1.69 & 1.69 & 0.00 & - & & \\
\hline 6.KTS & 1.98 & 2.36 & 2.36 & 1.41 & 1.41 & - & \\
\hline 7.KTM & 1.84 & 2.02 & 2.02 & 1.08 & 1.08 & 1.36 & - \\
\hline
\end{tabular}




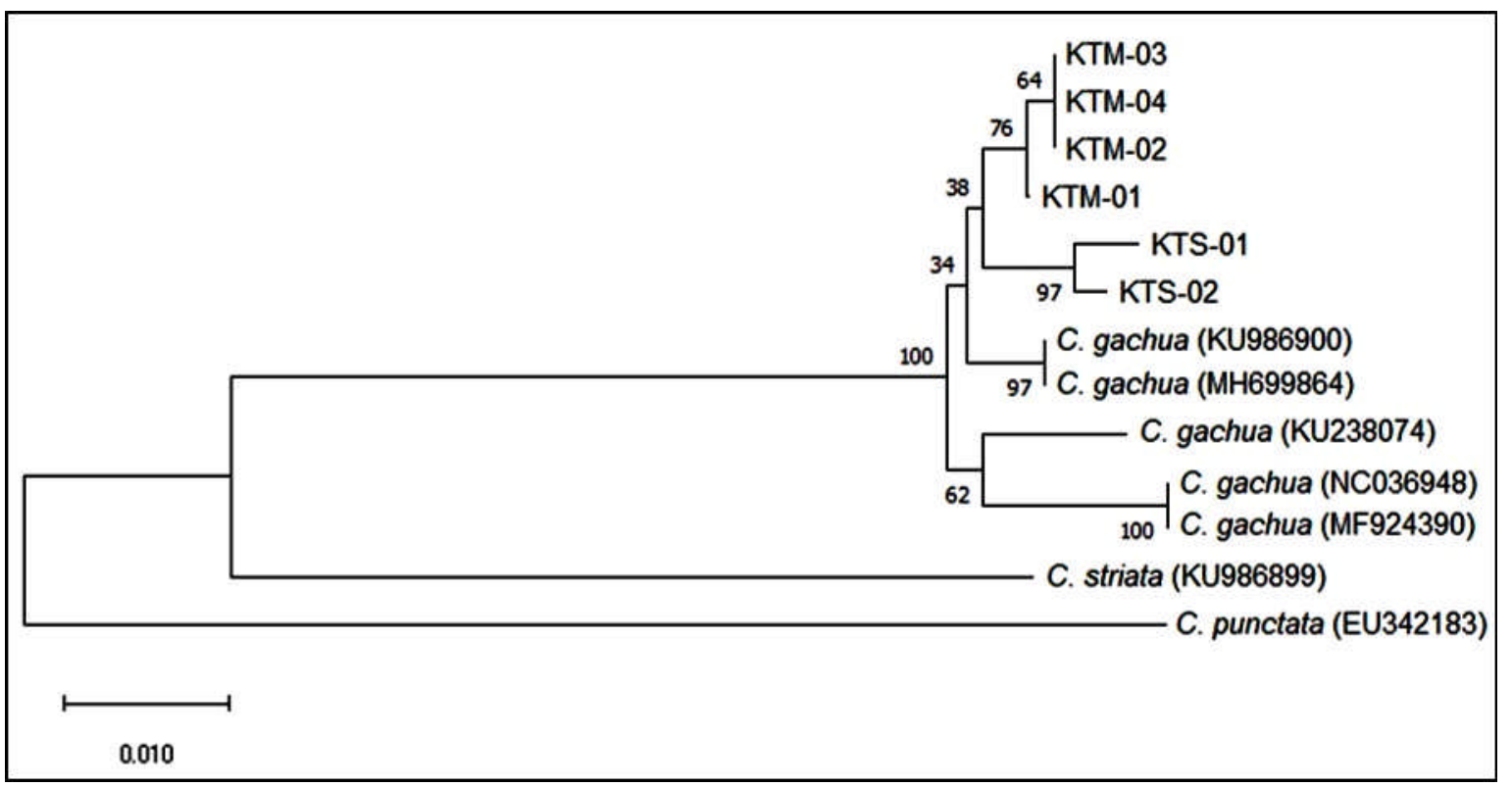

Figure 4. Neighbor-Joining phylogenetic tree of $C$. gachua inferred from DNA sequences of $16 S$ mitochondrial gene. KTM is the sample code of $C$. gachua from rice field irrigation at Donomulyo village, KTS is the sample code of $C$. gachua from Keji River, and other $C$. gachua was taken from GenBank.

with C. gachua from Keji River.

The $C$. gachua from rice field irrigation at Donomulyo village (East Java, Indonesia) was clade together with C. gachua from Keji River (Central Java, Indonesia), Malaysia, and Vietnam, whereas the other clade was $C$. gachua from China. The separation of the two clades was supported by genetic distance $1.86 \%$ and haplotype networking with 22 mutation points. Further study is needed to confirm whether $C$. gachua is cryptic species or is still conspecific with high genetic variation.

\section{Discussion}

The analysis of Pairwise Distance Calculation with Kimura 2 parameter model was used to analyze the genetic distance or the genetic relatedness of $C$. gachua from two populations investigated in this study and from GenBank. The genetic distance of $C$. gachua from the two populations was $1.36 \%$. This result had a higher value than that of Lakra et al. (2010) which found the genetic distance of $C$. gachua in India was about $0.41 \%$. However, the phylogenetic analysis revealed that $C$. gachua from the two populations were still grouped in one lineage together with $C$. gachua from Malaysia and Vietnam and genetically separated from China. The close genetic relationship between $C$. gachua from the two populations and $C$. gachua from Malaysia and Vietnam compared to China might be due to migration which would have been possible during periods of lower sea levels (Hall, 2002), when these land masses and island were connected and creating the ancient landmass of what is referred to as Sundaland (Voris, 2000). The Sundaland landmass would have appeared several times during the last ice age when sea levels were lower and would have also been present during earlier periods extending in the Miocene (Hall, 2012). The presence of Sundaland has been used to explain the otherwise unusual and disjunct distribution of freshwater fish species in Southeast Asia including dwarf snakehead.

The detected 9 variable sites, which all are transitions, indicated genetic divergence of $C$. gachua in both populations investigated in this study, rice field irrigation at Donomulyo Village (Malang, East Java) and Keji River (Magelang, Central Java). The high transitions obtained in this study agree with the regularity of mitochondrial DNA evolution in animals (Yang et al., 2014). In addition, the sequence data of $16 S$ rRNA region revealed that $C$. gachua from rice field irrigation at Donomulyo Village had lower average haplotype diversity and nucleotide diversity compared to $C$. gachua from Keji River, which indicated the abundant diversities of the fish species in Keji River, even though the sample number of $C$. gachua collected from Keji River is lower than that of $C$. gachua from rice field irrigation at Donomulyo Village. This is due to the 165 mitochondrial gene is a conserved gene, and nucleotide divergences among samples within a group may reflect genetic heterogeneity within a population (Cawthorn et al., 2012; Yang et al., 2014). In addition, different levels of genetic variation between dwarf snakehead wild populations can be related to population sizes and different pressures of exploitation. This is due to 
overfishing being a main factor causing the decrease in genetic variation in wild fish populations (Pinsky \& Palumbi, 2014). Furthermore, the finding, which revealed no share haplotype network between the two populations, indicated $C$. gachua from each population were specific and it can be used for molecular marker.

\section{CONCLUSION}

The 165 mitochondrial sequence data show genetic divergences and intraspecies genetic variation between $C$. gachua collected from two populations (rice field irrigation at Donomulyo Village, Malang, East Java and Keji River, Magelang, Central Java). Those populations form specific haplotypes without sharing with other populations. This finding can be used as a molecular marker for the two populations of $C$. gachua to assembly $16 S$ mitochondrial DNA library of $C$. gachua from Indonesia.

\section{ACKNOWLEDGEMENTS}

The authors would like to express sincere thanks to the Head of Laboratory of Genetics and Breeding, Faculty of Biology, Gadjah Mada University, for providing research facilities. In addition, the authors also thank Lukman Hakim, S.Si., for his kind help in drawing the sampling location map and providing valuable technical assistance in the laboratory.

\section{REFERENCES}

Ab Wahab, S.Z., Kadir, A.A., Hussain, N.H.N., Omar, J., Yunus, R., Baie, S., Mohd Noor, N., Hassan, I.I., Wan Mamood, W.H., Abd Razak, A., \& Wan Yusoff, W.Z. (2015). The effect of Channa striatus (Haruan) extract on pain and wound he aling of post-lower segment c esarean section women. Hindawi, 2015, ID 849647.

Arisuryanti, T., Firdaus, N.U.N., \& Hakim, L. (2020). Genetic characterization of striped snakehead (Channa striata Bloch, 1793) from Arut River, Central Kalimantan inferred from COI mitochondrial gene. AIP Conference Proceedings, 2260, 020001. https://doi.org/10.1063/5.0015905

Ahmed, M.S., Dina, S.R., Nahar, L., Islam, N.N., \& Al Reza, H. (2018). Molecular characterization of Channa species from Bangladesh based on Cytochrome c Oxidase Subunit I (COI) gene. FishTaxa, 3(4), 87-93.

Cawthorn, D.M., Steinman, H.A., \& Witthuhn, R.C.
(2012). Evaluation of the 16S and 12S rRNA genes as universal markers for the identification of commercial fish species in South Africa. Gene, 491 (1), 40-48. DOI: 10.1016/j.gene.2011.09.009

Conte-Grand, C., Britz, R., Dahanukar, N., Raghavan, R., Pethiyagoda, R., Tan, H.H., Hadiaty, R.K., Yaakob, N.S., \& Ruber, L. (2017). Barcoding snakeheads (Teleostei, Channidae) revisited: Discovering greater species diversity and resolving perpetuated taxonomic confusions. PLOSONE, 12(9), e0184017. https://doi.org/10.1371/ journal.pone.0184017

Faddagh, M.S., Husain, N.A., \& Al-Badran, A.I. (2012). Usage mitochondrial 16SrRNA gene as molecular marker in taxonomy of Cyprini fish species (Cyprinidae: Teleostei). Journal of King Abdulaziz University-Marine Sciences, (23)1, 39-49.

Hall, R. (2002). Cenozoic geological and plate tectonic evolution of SE Asia and the SW Pacific: computerbased reconstructions, model and animations. Journal of Asian Earth Sciences, 20, 353-431. https://doi.org/10.1016/S1367-9120(01)00069-4

Hall, R. (2012). Sundaland and Wallacea: Geology, Plate Tectonics and Palaeogeography. in: Biotic Evolution and Environmental Change in Southeast Asia, (Eds.) D.J. Gower, J.E. Richardson, B.R. Rosen, L. Rüber, S.T. Williams, Cambridge University Press. UK, pp. 32-78

Gustiano R., Kurniawan K., \& Kusmini, I.I. (2021). Bioresources and diversity of snakehead, Channa striata (Bloch 1793): a proposed model for optimal and sustainable utilization of freshwater fish. IOP Conf. Series: Earth and Environmental Science, 762 (012012), 1-13. doi:10.1088/1755-1315/762/ $1 / 012012$

Hariati, A.M., Yuniarti, A., Endariani., Kusuma, W.E., \& Wiadnya, D.G.R. (2019). Albumin and enzyme profiles of dwarf snakehead, Channa gachua caught from River Brantas, East Java. Journal of Physics: Conference Series, 1146, 012041. 10.1088/1742-6596/1146/1/ 012041

Hossain, M.A.M., Uddin, S.M.K., Chowdhury, Z.Z., Sultana, S., Johan, M.R., Rohman, A., Erwanto, Y., \& Ali, M.E. (2019). Universal mitochondrial $16 S$ rRNA biomarker for mini-barcode to identify fish species in Malaysian fish products. Food Additives \& Contaminants Part A, 36(4), 493-506. 
DOI: 10.1080/19440049.2019.1580389

IImi, W., \& Arisuryanti, T. (2018). Composition of Mitochondrial DNA 165 Nucleotide of Dwarf Snakehead (Channa gachua Hamilton, 1822) from Keji River, Magelang, Central Java. Journal of Tropical Biodiversity and Biotechnology, 3, 57-61. https://doi.org/10.22146/jtbb.35613

Kottelat, M. (2013). The fishes of the inland waters of Southeast Asia: a catalogue and core bibliography of the fishes known to occur in freshwaters, mangroves and estuaries. The Raffles Bulletin of Zoology, 2013 (Suppl. 27), 1-663.

Kumar, S., Stecher, G., Li, M., Knyaz, C., \& Tamura, K. (2018). MEGA X: Molecular Evolutionary Genetics Analysis across computing platforms. Molecular Biology and Evolution, 35, 1547-1549. DOI: $10.1093 / \mathrm{molbev} / \mathrm{msy} 096$

Lakra, W.S., Goswami, M., Gopalakrishnan, A., Singh, D.P., Singh, A., \& Nagpure, N.S. (2010). Genetic relatedness among fish species of Genus Channa using mitochondrial DNA genes. Biochemical Systematics and Ecology, 38, 12121219. doi:10.1016/j.bse.2010.12.012

Maddison, W. P., \& D.R. Maddison. (2019). Mesquite: a modular system for evolutionary analysis. Version 3.61 (http://www.mesquiteproject.org accessed 2 March 2020).

Palumbi, S.R. (1996). Nucleid acids II: The Polymerase Chain Reaction. in: Molecular Systematic, (Eds.) D.M. Hillis, C. Moritz, B.K. Mable, Sinauer Associates. Sunderland. Massachusetts, pp. 205247.

Pinsky, M.L., \& Palumbi, S.R. (2014). Meta-analysis reveals lower genetic diversity in overfished populations. Molecular Ecology, 23, 29-39

Rozas, J., Ferrer-Mata, A., Sánchez-DelBarrio, J.C.,
Guirao-Rico, S., Librado, P., Ramos-Onsins, S.E., \& Sánchez-Gracia, A. (2017). DnaSP 6: DNA sequence polymorphism analysis of large datasets. Molecular Biology and Evolution, 34, 3299-3302. DOI: $10.1093 / \mathrm{molbev} / \mathrm{ms} \times 248$

Saad, Y.M., Shaikh Omar, A.K.M., \& Gharbawi, W.M. (2019). Evaluation of molecular diversity in some Red sea parrotfish species based on mitochondrial $16 S$ ribosomal RNA gene sequence variations. Research Journal of Biotechnology, 14(12), 8-21.

Satoh, T.P., Miya, M., Mabuchi, K., \& Nishida, M. (2016). Structure and variation of the mitochondrial genome of fishes. BMC Genomics, 17, 719.

Srinivasan, R., Karaoz, U., Volegova, M., MacKichan, J., Kato-Maeda, M., Miller, S., Nadarajan, R., Brodie, E.L., Lynch, S.V. (2015). Use of 16 SrRNA gene for identification of a broad range of clinically relevant bacterial pathogens. PLOS ONE, 10(2), e0117617.

Tanomtong, A., Supiwong, W., Jearranaiprepame, P., Khakhong, S., Kongphironchuen, C., Getlekha, N. (2014). A new natural autotetraploid and chromosomal characteristics of dwarf snakehead fish, Channa gachua (Perciformes, Channidae) in Thailand. Cytologia, 79(1), 15-27.

Voris, H.K. 2000. Maps of Pleistocene sea levels in Southeast Asia: shorelines, river systems and time durations. Journal of Biogeography, 27, 1153-1167.

Yang, L., T. Zongqing, D. Wang, L. Xue, M. Guan, T. Huang \& R. Li. (2014). Species identification through mitochondrial rRNA genetic analysis. Science Report, 14, 1-11

Zhou, J., Deng, Y., Zhou, G. (2019). The mitochondrial genome of dwarf snakehead Channa gachua (Perciformes: Channidae) and phylogenetic analysis. Mitochondrial DNA Part $B$, 4(1), 1146-1147. 